\title{
American Muslim Women, Religious Authority, and Activism: More Than a Prayer
}

\author{
Juliane Hammer
}

Austin: The University of Texas Press, 2012. 271 pages.

In American Muslim Women, Religious Authority, and Activism: More Than a Prayer, Juliane Hammer traces recent conversations around gender and religion within American Muslim communities. Taking as a starting point the mixedgender Friday prayer led by Amina Wadud in 2005, the author examines how questions of gendered religious authority have been negotiated through interpretations of scripture and religious laws, challenges to constructions of tradition and community, contestations surrounding prayer spaces, and representations of Muslim women in the media and autobiographical narratives. 
The result is a valuable and insightful mapping of some of the major scholars, activists, and public figures engaged in work related to women, gender, and Islam in North America. Based on an analysis of texts produced by female American Muslim scholars and writers since the 1980s and especially within the past decade, the book highlights women's contributions to debates around women-led prayer, Qur'anic interpretations, women's spaces in mosques, and women's leadership within Muslim communities, among other issues. Hammer acknowledges that of many of the texts she studies have a "progressive" leaning, but frames this as itself a research finding that reflects the perspectives and voices most likely to be published or otherwise highlighted within an American context.

Hammer's book begins with a chapter called "A Woman-Led Friday Prayer: March 18, 2005," which reconstructs this event based on written reflections, media coverage, and video footage. In careful detail, she covers the publicity and press conference leading up to the prayer as well as what happened at the prayer itself, including the text of a section of Wadud's sermon, descriptions of the worshippers and journalists in attendance, and postprayer reflections from key participants. Chapter 2, "Women Leading Prayers: Tracing the Debate," examines the media and online debates that arose among Islamic scholars, academics, and Muslim community activists during the time leading up to, on the day of, and right after the prayer event.

Together, these two chapters provide a comprehensive portrait of a moment that continues to resonate in North American Muslim communities, and the detailed record provided is one of the book's unique strengths. Although Hammer convincingly argues that the prayer marked a catalytic moment in discussions of religious authority and woman-led prayer, particularly in North America, she avoids romanticizing or simplifying the event, by pointing both to organizer Asra Nomani's celebration of the prayer as an unqualified success and to Wadud's own reservations about how the event was organized and came to define her public image as a scholar.

In the remainder of the book, the author highlights how topics related to gender, authority, and leadership have been discussed among American Muslim writers and activists through various angles. Chapter 3, "Gender Justice and Qur'anic Exegesis," looks at how Qur'anic interpretation has been taken up by such scholars as Aysha Hidayatullah, Riffat Hassan, and Nimat Barazangi, among others. Building on Sa'diyya Shaikh's concept of a "tafsir of praxis," Hammer proposes the concept of "embodied tafsir" as an acknowledgement that exegesis happens not only through textual encounters, but also through social and bodily engagements with religious practices and principles. She an- 
alyzes two sermons given by Wadud - Cape Town (1994) and New York City (2005) - as examples of her tafsìr praxis.

Chapter 4, "History, Women's Rights, and Islamic Law," discusses how scholars have grappled with the particular question of woman-led prayer and with broader systems of potentially problematic texts or patriarchal histories in interpreting Islamic law. The chapter pays particular attention to Kecia Ali's work on sexual ethics within Islam and to Azizah al-Hibri's and Hassan's writing on women's rights within Islamic law. It ends by looking at several women's writings about the figure of Hagar as an example of the efforts of some women to reclaim historical female religious figures as role models.

In the next chapter, "Authority, Tradition, and Community," Hammer examines the ways in which religious authority has historically been constructed within Islamic contexts. The chapter considers women's engagement with the authority attributed to the Qur'an and the Sunnah and examines writings by Wadud, Barazangi, Asma Barlas, Ali, Ayesha Chaudhry, and other female scholars, as well as by Khaled Abou El Fadl. The chapter concludes by examining the education and training undertaken by (or available to) female Muslim scholars in the United States and arguing that female scholars need to build interpretive communities so that their authority will have relevance outside of narrow academic contexts.

Chapter 6, "Space, Leadership, and Voice," explores the relationship among gendered religious spaces, leadership positions, and self-expression. Exploring the history of North American mosques and their women's sections through Zarqa Nawaz's documentary Me and the Mosque and Nomani's activism around mosque spaces, this chapter analyzes the debates about gender segregation in Muslim spaces. It links these to broader understandings of women's leadership, also highlighting Ingrid Mattson's writing and her role as the first female president of the Islamic Society of North America and framing women's voices as a way of claiming that space and leadership.

In Chapter 7, "Media, Representation(s), Politics," Hammer investigates how American Muslim women have responded to the media's negative portrayal of Muslim women. She describes the Wadud prayer as a self-conscious response to images of Muslim women as silent and oppressed, and looks closely at the media experiences of both Nomani (positioned as a lone warrior figure) and Wadud (a far more reluctant media personality). The chapter also draws attention to Mohja Kahf's academic writing on western representations of Muslim women and to her fiction and poetry. More broadly, this chapter highlights the increasing amount of work produced by American Muslim 
women that directly challenges media images while pointing to the complexities involved in responding to narrow representations of Muslim women without reinforcing other stereotypes.

The following chapter, "Memoirs, Narratives, and Marketing," focuses on personal narrative writing as an additional form through which Muslim women are speaking out. Here, she cites the examples of autobiographies by Nomani, Asma Gull Hasan, Leila Ahmed, and Sumbul Ali-Karamali, as well as several edited collections. Hammer points to the role of these texts in challenging stereotypes, explaining Islam to a western audience, chronicling personal religious journeys, and building communities. She further talks about the risks involved in speaking as a member of a certain group, as well as the challenges of finding a place for American Muslim writers with relation to first- or third-world literatures and within the Orientalist and imperialist discourses that shape the broader context in which these women write.

The book's final chapter, "Covers and Other Matters: Concluding Thoughts," takes a brief look at issues not covered in more detail. The first of these is hijab, a topic whose absence from the work at large is welcome. Given the predominance of veil-related writing when it comes to literature on Muslim women, Hammer's focus on a myriad of other issues is a refreshing change. In addition, it serves not only as a critique of the primacy so often accorded to the headscarf, but also as a model for how to write about Muslim women without prioritizing questions of clothing. Hammer extends her discussion of hijab to an analysis of a different kind of covering: book covers associated with writing by and about Muslim women. Images of thirty-two such covers are included at the chapter's end.

Other topics raised here include the impact of racial dynamics in American Muslim communities (an especially noticeable absence within the analysis), the presence of American Muslim women in academia, the role of men in discussions of gender and religion, and the transnational conversations and networks growing around similar matters. There is, indeed, much to be added to Hammer's study by a broader examination of each of these issues - and others, such as the role and presence of converts within these debates - and each represents important ground for future research. It would also be interesting to further extend this study to look at how these themes are discussed outside of formally published texts and among more conservative Muslim women.

American Muslim Women, Religious Authority, and Activism: More Than a Prayer is a valuable analysis of the voices of an impressive range of Muslim women. The careful division of chapters emphasizes the numerous approaches that American Muslim women are taking with regard to the scriptural, legal, 
cultural, traditional, personal, and experiential dimensions of gendered religious authority within a Muslim context. Of particular interest within broader fields of work on American Muslim communities or on gender and Islam, this book provides a detailed survey that is accessible to those less familiar with the topics discussed and serves as a useful reference and synthesis for those more deeply engaged in related research.

Krista Riley Doctoral Candidate, Communications Studies Concordia University, Montreal, QC, Canada 